(C) Middle East Institute. This article is for personal research only and may not be copied or distributed in any form without the permission of The Middle East Journal.

\title{
The European Union and Israel's Occupation: Using Technical Customs Rules as Instruments of Foreign Policy
}

Neve Gordon and Sharon Pardo

\begin{abstract}
This article describes the rules of origin dispute between the European Union and Israel, and argues that these technical customs rules are also instruments of foreign policy. Although the rules have had no direct impact on Israel's industry in the Occupied Territories, they have bolstered the European Union's self-identification as a "normative power" while constituting an important legal precedent that has served to legitimize other actions against Israel's occupation.
\end{abstract}

I January 2005, the European Union decided to implement fully the rules of origin (ROO) clause $^{1}$ of the 1995 European Community (EC)-Israel Association Agreement ${ }^{2}$ and to subject products manufactured in the territories Israel had occupied during the 1967 Arab-Israeli war to customs duty. The EU's decision spurred a scholarly debate about its legal basis, ${ }^{3}$ the implications it would likely have on Europe's normative

Neve Gordon teaches at the Department of Politics and Government, Ben-Gurion University of the Negev. He is the author of Israel's Occupation (University of California Press, 2008) and coauthor (with Nicola Perugini) of The Human Right to Dominate (Oxford University Press, 2015).

Sharon Pardo teaches at the Department of Politics and Government, Ben-Gurion University of the Negev. He is the author of Normative Power Europe Meets Israel (Lexington, 2015, forthcoming), and, with Joel Peters, the coauthor of Uneasy Neighbors: Israel and the European Union (Lexington, 2010) and Israel and the European Union: A Documentary History (Lexington, 2012).

The authors appear in alphabetical order and acknowledge equal contribution. The authors would like to thank Hannah Moscovitz for her research assistance.

1. European Commission, "Notice to Importers: Imports from Israel into the Community," Official Journal of the European Communities, \#C 208/02, January 25, 2005, available as Document 5/12 in Israel and the European Union: A Documentary History, eds. Sharon Pardo and Joel Peters (Lanham, MD: Lexington Books, 2012), pp. 376-77.

2. European Communities, "Euro-Mediterranean Agreement Establishing an Association between the European Communities and Their Member States of the One Part, and the State of Israel, of the Other Part," Official Journal of the European Communities, \#L 147/3, June 21, 2000, available as Document 4/23 in Israel and the European Union, eds. Pardo and Peters, pp. 229-53.

3. Moshe Hirsch, "Asymmetrical Factor Endowments, Progressive Rules of Origin and Commercial Cooperation in the Middle East," KAS Working Paper, 1998; Esa Paasivirta, "EU Trading with Israel and Palestine: Parallel Legal Frameworks and Triangular Issues," European Foreign Affairs Review, Vol. 4, No. 3 (1999), pp. 305-26; Moshe Hirsch, "Rules of Origin as Trade or Foreign Policy Instruments? The European Union Policy on Products Manufactured in the Settlements in the West Bank and the Gaza Strip," Fordham International Law Journal, Vol. 26, No. 3 (2002), pp. 572-94; Christian Hauswaldt, "Problems under the EC-Israel Association Agreement: The Export of Goods Produced in the West Bank and the Gaza Strip under the EC-Israel Association Agreement," European Journal of International Law, Vol. 14, No. 3 (June 2003), pp. 591-611; Lior Zemer and Sharon Pardo, "The Qualified Zones in Transition: Navigating the Dynamics of the Euro-Israeli Customs Dispute," European Foreign Affairs Review, Vol. 8, No. 1 (2003), pp. 51-75; Elena Aoun, "European Foreign Policy and the Arab-Israeli Dispute: Much Ado About Nothing?" European Foreign Affairs Review, 
positions, ${ }^{4}$ and on whether it is consistent with the EU's policies involving rules of origin in other regions. ${ }^{5}$ Surprisingly, though, few scholars have examined the actual economic and political implications of applying the ROO on Israeli products manufactured in the Jewish settlements in the occupied West Bank and the Golan Heights. ${ }^{6}$ It is important to determine whether, for example, the implementation of the ROO has actually had an impact on Israeli industry in the Occupied Territories or on Israel's settlement policies, since such questions help us gain insight into how technical customs rules can be deployed as instruments of foreign policy and whether they really have an impact. ${ }^{7}$

We begin with a brief overview of the ROO, followed by a description of the political processes leading to the EU's decision to enact the ROO clause on products manufactured in Jewish settlements in the Territories. We claim that while the decision was carried out in accordance with the stipulations of the 1995 EC-Israel Association Agreement, the decision to apply the ROO was also informed by the EU's displeasure with Israel's settlement policy in the West Bank, Gaza Strip, East Jerusalem, and the Golan Heights. Hence, we contend that the implementation of the ROO should also be understood as a form of political conditionality carried out by the EU towards Israel. Next, we briefly describe the Israeli export industry in the Territories, showing that the application of the ROO has had no tangible impact on this industry, on the Israeli economy as a whole, or even the settlement project in particular.

We go on to explain why the direct impact has been insignificant, emphasizing that during negotiations the EU conceded that products from the Territories would continue to be labeled "Made in Israel," because currently, with few exceptions, labeling rules are determined by each EU member state. We claim, however, that the application of the ROO has had an incremental impact, since the rules have influenced some EU member states to begin addressing the labeling issue. They have further served as the basis for the publication of new EU guidelines prohibiting the

[Continued from previous page]

Vol. 8, No. 3 (2003), pp. 289-312; Guy Harpaz, "The Dispute Over the Treatment of Products Exported to the European Union from the Golan Heights, East Jerusalem, the West Bank and the Gaza Strip: The Limits of Power and the Limits of the Law," Journal of World Trade, Vol. 38, No. 6 (2004), pp. 1049-58; Sharon Pardo and Joel Peters, Uneasy Neighbors: Israel and the European Union (Lanham, MD: Lexington Books, 2010).

4. Guy Harpaz, "Mind the Gap: Narrowing the Legitimacy Gap in EU-Israeli Relations," European Foreign Affairs Review, Vol. 13, No. 1 (2008), pp. 117-37; Guy Harpaz and Eyal Rubinson, "The Interface Between Trade, Law, Politics and the Erosion of Normative Power Europe: Comment on Brita," European Law Review, Vol. 35, No. 4 (2010), pp. 551-70; Sharon Pardo and Lior Zemer, "Bilateralism and the Politics of European Judicial Desire," The Columbia Journal of European Law, Vol. 17, No. 2 (Spring 2011), pp. 263-305.

5. Pardo and Zemer, "Bilateralism and the Politics of European Judicial Desire."; Eyal Rubinson, "More than Kin and Less than Kind: The Status of Occupied Territories under the European Union Bilateral Trade Agreements," KAS Working Paper No. 97 (2011).

6. Robert Mason tried to identify the price of peace between Israelis and Palestinians by considering the issues of Palestinian labor, refugees, and the future economic status of Jerusalem. See Robert Mason, "The Price of Peace: A Reevaluation of the Economic Dimension in the Middle East Peace Process," The Middle East Journal, Vol. 67, No. 3 (Summer 2013), pp. 405-25.

7. For a general analysis of the political utilization of the ROO, see Moshe Hirsch, "The Politics of Rules of Origin," in The Politics of International Economic Law, eds. Tomer Broude, Marc L. Busch, and Amelia Porges (Cambridge, UK: Cambridge University Press, 2011), pp. 317-36. 
allocation of the EU's funds to Israeli companies, public bodies, and nongovernmental organizations (NGOs) working within the Israeli settlements (hereinafter "EU guidelines"). ${ }^{8}$ Finally, they have, even if by association, given legitimacy to the decision of private companies and financial institutions such as the Dutch cooperative Pensioenfonds voor Gezondheidszorg, Geestelijke en Maatschappelijke (PGGM) pension fund to stop investing in five Israeli banks because of "their involvement in financing Israeli settlements" in the Territories. ${ }^{9}$ We conclude by advancing two arguments: First, the EU-Israeli case suggests that the current separation between the ROO and labeling rules defangs the ROO and therefore hinders the rules' ability to become an effective instrument of European foreign political policy. Nonetheless, the ROO do have an incremental political impact, since they serve as the basis of legitimization for other policy decisions of the EU, member states, and private corporations. Second, the decision to implement the ROO has had two domestic effects: it has served to legitimize EU trade with Israel and to bolster the Union's selfidentification as a "normative power."10

\section{THE RULES OF ORIGIN}

Described as the economic nationality of products, the ROO outline the criteria used to determine in which country a product originates. The ROO are divided into two types: non-preferential and preferential. While the former is connected to enforcing trade remedies of a general nature, such as antidumping and countervailing duties, as well as for compiling statistics on global trade flows, the latter is used exclusively within preferential trade agreements (PTAs) to determine which goods are eligible for a reduced tariff rate within a free-trade area. ${ }^{11}$ The ROO appear in practically all PTAs and are used primarily to prevent trade deflection — a situation in which a third country not party to a PTA ships a product through a country that is benefiting from the lower tariff and thus illegally enjoys a custom reduction.

The ROO are informed by two underlying assumptions. First, that the origin of a product can be determined, and second, that the territory from which the product originates is neither disputed nor occupied. Most of the difficulties involving the ROO

8. European Commission, "Guidelines on the Eligibility of Israeli Entities and their Activities in the Territories Occupied by Israel since June 1967 for Grants, Prizes and Financial Instruments Funded by the EU from 2014 Onwards," Official Journal of the European Union, \#C 205/9 (July 19, 2013), available on the European Union External Action website, http://eeas.europa.eu/delegations/israel/documents/related-links/20130719_guidelines_on_eligibility_of_israeli_entities_en.pdf. For an analysis of the Guidelines consult Neve Gordon and Sharon Pardo, "Normative Power Europe and the Power of the Local," Journal of Common Market Studies (forthcoming), DOI: 10.1111/jcms.12162.

9. PGGM, "Statement Regarding Exclusion of Israeli Banks," PGGM English-language website, January 8, 2014, https://www.pggm.nl/english/what-we-do/exclusions/Documents/StatementPGGM-exclusion-Israeli-banks.pdf.

10. Ian Manners, "Normative Power Europe: A Contradiction in Terms?" Journal of Common Market Studies, Vol. 40, No. 2 (2002), pp. 235-58.

11. Olivier Cadot and Jaime de Melo, "Why OECD Countries Should Reform Rules of Origin," World Bank Research Observer, Vol. 23, No. 1 (March 2008), pp. 77-105; Hatem Mabrouk, "Rules of Origin as International Trade Hindrances," Entrepreneurial Business Law, Vol. 5, No. 1 (2010), pp. 97-176; Hirsch, "Rules of Origin as Trade or Foreign Policy Instruments?" 
have to do with the first assumption, because in reality many products are manufactured in several countries, in the so-called global factory. ${ }^{12}$ Hence, for the past four decades it has been acknowledged that ascertaining a product's country of origin has become increasingly difficult with the internationalization of production processes. Over the years several economic tests have been developed to determine the origin of a product that is manufactured in several countries, ${ }^{13}$ and while disputes about this issue continue to arise, in this case the EU and Israel do not disagree about the origin of the products but rather about the legal status of the territory whence the products originate.

The second underlying assumption of the ROO is that political borders are both clear-cut and agreed-upon. This further suggests that issues relating to the origin of a product are interlaced with questions about legal territorial sovereignty, ${ }^{14}$ and indeed that the ROO presuppose such sovereignty. Currently, however, there are over 20 disputed or occupied territories around the globe which either export goods or are believed to hold considerable natural resources. Moreover, each of the countries laying claims to these territories has signed PTAs, which include the ROO clauses, indicating that the legal status of the territory is of utmost importance. The Occupied Territories are among the few regions where the status of the territory has actually led to a serious examination of how it should affect the ROO clauses signed by Israel and therefore can serve as a case study for analyzing the use of the ROO as instruments of foreign policy.

\section{CUSTOM RULES AS INSTRUMENTS OF EUROPEAN FOREIGN POLICY}

By the end of 2008, the EU had 35 preferential trade agreements, making the Union's network of PTAs the largest in the world. ${ }^{15}$ In addition to the liberalization of trade, the declared motivation of PTAs, particularly those signed with non-EU Mediterranean countries in the framework of the Euro-Mediterranean Partnership (EMP, also known as the Barcelona Process and, as of 2008, the Union for the Mediterranean), includes the promotion of political stability through economic prosperity. The idea, as Alan Winters point out, is to ensure against disruptive social or economic conditions that could spill over and adversely affect EU member states. ${ }^{16}$ Hence, the EU not only recognizes the economic importance and impact of the trade agreements it signs, but also claims to use them in order to advance political goals. The former European commissioner for trade, Karel De Gucht, even avers that the EU's trade policy is one of the key instruments to promote rule of law and respect for human rights, which he characterizes

12. Joseph Grunwald and Kenneth Flamm, The Global Factory: Foreign Assembly in International Trade (Washington, DC: Brookings Institution, 1985).

13. For the three economic tests that are commonly employed to define the general principle more precisely consult Hirsch, "Rules of Origin as Trade or Foreign Policy Instruments?"

14. Hauswaldt, "Problems under the EC-Israel Association Agreement."

15. Raymond J. Ahearn, "Europe's Preferential Trade Agreements: Status, Content, and Implications," Congressional Research Service Report for Congress, \#R41143, March 3, 2011, www.fas.org/ sgp/crs/row/R41143.pdf, p. 6.

16. L. Alan Winters, "EU's Preferential Trade Agreements: Objectives and Outcomes," in The External Economic Dimensions of the European Union, eds. Pitou van Dijck and Gerrit Faber (The Hague: Kluwer Law International, 2000), p. 202. 
as "the shared values that underpin the European construction." 17 The implementation of the ROO in this context should be considered as an EU attempt to reassert the Green Line (which Israel erased by, inter alia, building and expanding Jewish settlements) and a message to Israel that it will not be profitable to build industry in the Territories.

\section{THE ROO AND THE 1995 EC-ISRAEL ASSOCIATION AGREEMENT}

The fourth protocol to the 1995 EC-Israel Association Agreement defines the concept of "originating products" and the methods of administrative cooperation between the parties to the agreement. The protocol specifies the origin criteria for different categories of products. Although the stipulations regarding the ROO are well defined, the agreement does not offer a specific definition of what constitutes the "territory of the State of Israel." Based on the secret 1971 "Schuman Document on the Middle East," the first official EC declaration on the Arab-Israeli conflict from November 6, 1973, ${ }^{18}$ as well as several other declarations made over the years, the EU signatories to this agreement consider the "territory of the State of Israel" as the area within the borders determined by the 1949 armistice agreements. They subscribe to United Nations Security Council Resolutions 242 and 338, which serve for the 28 EU member states as the basic contours for any future agreement pertaining to the Territories and the creation of a Palestinian State. Israel, on the other hand, prefers to leave the exact demarcation of its borders ambiguous, not only because it unilaterally applied its civilian laws to East Jerusalem in July 1967 and the Golan Heights in December 1981, but because it considers the Jewish settlements in the West Bank as integral to the State. ${ }^{19}$

Ironically, perhaps, the European Commission raised the question of the origin of products produced in the Territories as a result of another investigation. In 1993, the EC suspected that Israeli orange juice producers were using Brazilian juice concentrate in products labeled "Israeli juice" in order to enjoy tax benefits under the EC-Israeli agreement (a classic case of trade deflection). Although the European Commission was unable to find conclusive evidence of fraud, it published a "First Notice to Importers," in November 1997, informing European Community importers that there were grounds for doubt about the validity of the origin certificates for orange juice coming from Israel and that the importers would be liable for duty recovery. This investigation into an issue unrelated to the Territories seems to have served as the impetus for questioning the origins of goods exported to the Union from the territories Israel had occupied in 1967, since in the same notice the EU further informed European Community importers of problems relating to Israel's implementation of the ROO regarding products from Israeli settlements in the Territories. ${ }^{20}$

17. Karel De Gucht, "Trade Policy and Human Rights," (address, Socialists and Democrats Conference, "Can Trade Policy Improve Human Rights?" Brussels, October 13, 2010), available on the European Commission website, http://trade.ec.europa.eu/doclib/docs/2010/october/tradoc_146727.pdf, p. 2.

18. "The Shuman Document on the Middle East, 13 May 1971," Document 2/14 in Israel and the European Union, eds. Pardo and Peters, p. 101; "EPC Middle East Declaration, 6 November 1973," Document 2/20 in Israel and the European Union, eds. Pardo and Peters, pp. 106-7.

19. Neve Gordon, Israel's Occupation (Berkeley, CA: University of California Press, 2008).

20. European Commission, "Notice to Importers: Importations from Israel into the Community," Official Journal of European Communities, \#C 338/12, November 8, 1997; available as Document 4/16 in Israel and the European Union, eds. Pardo and Peters, p. 219. 
In May 1998, the European Commission concluded that according to UN General Assembly and Security Council resolutions, no Israeli settlement in the West Bank, the Gaza Strip, East Jerusalem, or the Golan Heights could be considered part of the territory of the State of Israel. Thus, exports originating from Israeli settlements in the Territories did not qualify for preferential treatment under the terms of the EC-Israel Association Agreement, and, consequently, any origin certificates issued by Israel for goods produced in Jewish settlements contravened the agreement's fourth protocol on the ROO and should have been brought to an end. ${ }^{21}$

Initially, Israel denounced the European declarations, characterizing them as an attempt to impose sanctions on Israel. The discussions surrounding this dispute were fractious and for several years the two sides failed to reach a satisfactory solution. The EU insisted on implementing the ROO not only due to its resolve to abide by the 1995 agreement, but, as we explain below, also because the lack of implementation would contradict another legally binding agreement that it had signed. Consequently, Israel had to succumb to European pressure, and in December 2004, the EC-Israel Joint Customs Cooperation Committee drafted a "technical arrangement" to end this dispute. One month later, a new notice was issued to customs operators, informing them that "products coming from places brought under Israeli Administration since 1967 are not entitled to benefit from preferential treatment" under the agreement and therefore the full customs duty should apply to those products. ${ }^{22}$

\section{THE “TECHNICAL ARRANGEMENT”}

Under the terms of the arrangement that went into effect in February 2005, Israeli customs authorities are required to identify the place of production for all products exported to the EU. In other words, Israeli products from the Territories continue to be labeled "Made in Israel" but Israel is now obligated to indicate on all origin certificates the precise name of the city, village, or industrial zone, with its accompanying postal code, and where production conferring originating status has taken place. As we argue below, the ability to continue labelling these products "Made in Israel" was crucial to undermining the direct impact of the ROO on Israeli industry in the Territories, as well as on Israel's settlement project. ${ }^{23}$

21. European Commission, "Communication from the Commission to the Council and the European Parliament: Implementation of the Interim Agreement on Trade and Trade Related Matters between the European Community and Israel," European Commission, SEC \#695 final, May 12, 1998, pp. 7-8; available as Document 4/18 in Israel and the European Union, eds. Pardo and Peters, pp. 222-23. Two further EU fact-finding missions to Israel, in September 1998 and October 1999, established that Israel was in breach of the provisions concerning the ROO. See Zemer and Pardo, "The Qualified Zones in Transition."

22. European Commission, "Notice to Importers," 1997, in Israel and the European Union, eds. Pardo and Peters, pp. 376-77.

23. Following the EU's foreign ministers' May 2012 "commitment to fully and effectively implement existing EU legislation and the bilateral arrangements applicable to settlement products," in August 2012, a "New Notice to Importers" was issued along with an up-to-date list of non-eligible locations. Operators were reminded yet again that "the preferential treatment will be refused to the goods for which the proof of origin indicates that the production conferring originating status has taken place in a location within the territories brought under Israeli administration since June 1967." 


\title{
THE POLITICS INFORMING THE RULES OF ORIGIN
}

Officially, the EU insists that its decision to implement the ROO is a "technical matter." Responding to Israeli claims that the imposition of the ROO was comparable to imposing sanctions on Israel, the EU's commissioner for external relations, Chris Patten, stated in May 2001 at the European Parliament that:

\begin{abstract}
preferential access to Community markets for exports originating in Israeli settlements in the West Bank and Gaza Strip and in East Jerusalem and the Golan Heights "contravenes agreed rules of origin since these territories do not form part of the State of Israel under public international law." . . . Our decisions will be entirely based on the law and its technical application case by case. ${ }^{24}$
\end{abstract}

This does not mean, however, that at least for some EU diplomats the decision to implement the ROO was a way of using technical customs rules as instruments of European foreign policy in order to try to change Israel's policies in the Territories. In April 2001, The Telegraph reported:

The European Union is preparing to strip Israel of privileged trade access as a punishment for the use of 'excessive force' against the Palestinians. . . This means Israel will no longer be able to get away with exporting duty-free goods made at Jewish settlements in the West Bank and Gaza as if they were Israeli products. ${ }^{25}$

Three years later, The Guardian affirmed that the decision to impose the ROO on Israel was due to "the EU's displeasure at Israeli settlement policies, highlighting differences over the legitimacy of the pre-1967 border." ${ }^{26}$ Hence, it appears that the motivation for implementing the ROO was not merely due to "technical reasons," but also as an instrument for advancing European foreign policy; in this case, as a form of EU political conditionality in order to pressure Israel to stop fortifying its settlement project in the Territories.

[Continued from previous page]

See Council of the European Union (CEU), "Council Conclusions on the Middle East Peace Process: $3166^{\text {th }}$ Foreign Affairs Council Meeting, Brussels, 14 May 2012," CEU official website, www.consilium.europa.eu//uedocs/cms_data/docs/pressdata/EN/foraff/130195.pdf, p. 12; European Union, "Notice to Importers: Imports from Israel into the EU (2012/C 232/03)," Official Journal of the European Union, \#C 232/5 (August 3, 2012), http://eur-lex.europa.eu/legal-content/EN/TXT/PDF/? uri=OJ:C:2012:232:FULL\&from=EN. For the most recent list of non-eligible locations see European Commission (EC), "List of Non-Eligible Locations," February 1, 2013, EC webite, http://ec.europa. eu/taxation_customs/customs/technical-arrangement_postal-codes.pdf.

24. European Commission, "The Rt. Hon. Chris Patten, Commissioner for External Relations, Statement on the Situation in the Middle East, Plenary Session of the European Parliament, Strasbourg," European Commission, Speech/01/222, May 16, 2001; available as Document 4/27 in Israel and the European Union, eds. Pardo and Peters, pp. 259-62.

25. Ambrose Evans-Pritchard and Alan Philps, "EU Prepares to Punish Israel over Gaza Attacks," The Telegraph, April 26, 2001, www.telegraph.co.uk/news/worldnews/middleeast/israel/1317340/ EU-prepares-to-punish-Israel-over-Gaza-attacks.html.

26. Reuters, "EU Ends Tariff-Free Israeli Trade," The Guardian, August 5, 2004, www.theguardian.com/world/2004/aug/06/eu.israel. 


\section{EU DOUBLE STANDARDS?}

In addition to the explicit claims of EU officials that the strict adherence to the ROO has been technical, scholars have argued that the EU's decision is inconsistent with its policies in other regions. Eyal Rubinson, for example, compared the EU's stance towards Israel's occupation with its position on Western Sahara. ${ }^{27}$ He shows that even though Western Sahara is considered to be an occupied territory, the EU allowed Morocco trade benefits under its association agreement with respect to products (mainly from fisheries) originating from this region. The inconsistency of the application of the ROO suggests, in Rubinson's view, that the decision to implement them in the Israeli case was not merely technical, but also informed by the EU's desire to convey a strong political message to the Israeli government.

Others have also used the Western Sahara comparison to claim that the EU decision regarding the implementation of ROO with respect to the West Bank, the Gaza Strip, East Jerusalem, and the Golan Heights was politicized, and therefore informed by a degree of double standards. ${ }^{28}$ Following the July 2013 EU Guidelines prohibiting the allocation of the Union's funds to Israeli projects in the Territories, Avi Bell and Eugene Kontorovich also used the Morocco-Western Sahara case to argue that "in adopting the Guidelines, the Commission has set a double standard: it has one rule for the Jewish state, and a different one for the rest of the world." Not only do Bell and Kontorovich hold that the EU has set double standards, but based on this behavior and on the Union's working definition of anti-Semitism, they conclude that the EU is an anti-Semitic entity. ${ }^{29}$

There is, however, a crucial difference between the two cases, whose significance all of these scholars fail to underscore. Namely, that in the Western Sahara case the EU had signed a free-trade agreement (FTA) only with Morocco and not with any other entity that lays claim to the disputed territory, while in this case the EU had also signed a FTA with the Palestine Liberation Organization (PLO). In February 1997 the EC and the PLO signed an interim association agreement on trade and cooperation for the benefit of the Palestinian Authority (PA) of the West Bank and the Gaza Strip. Protocol Three of the Interim Association Agreement defines the concept of originating products and methods of administrative cooperation. ${ }^{30}$

The existence of parallel FTAs with Israel and the PLO and the fact that both agreements include ROO clauses is vital. Simply put, if the EU did not implement the ROO clause in the 1995 Association Agreement it had signed with Israel, it would

27. Rubinson, "More than Kin and Less than Kind."

28. Hirsch, "Rules of Origin as Trade or Foreign Policy Instruments?"; Harpaz, "The Dispute over the Treatment of Products Exported to the European Union from the Golan Heights, East Jerusalem, the West Bank and the Gaza Strip."

29. According to the EU's working definition of anti-Semitism, such an act also includes "applying double standards [to Israel] by requiring of it behavior not expected or demanded of any other democratic nation." Avi Bell and Eugene Kontorovich, "EU's Israel Grants Guidelines: A Legal and Policy Analysis," Kohelet Policy Forum Research Paper (Oct. 2013), http://kohelet.org.il/uploads/ file/EUs\%20Israel\%20Grants\%20Guidelines\%20A\%20Legal\%20and\%20Policy $\% 20$ Analysis $\% 20$ -\%20Kohelet\%20Policy\%20Forum\%20-\%20Final(1).pdf, pp. 9-10.

30. EC-PLO, "Euro-Mediterranean Interim Association Agreement," Official Journal of the European Communities, \#L 187/3, July 16, 1997, available on the EU Directorate General for Trade website, http://trade.ec.europa.eu/doclib/docs/2004/june/tradoc_117751.pdf. 
be in breach of the Interim Association Agreement it had signed with the PLO for the benefit of the PA. As was held by the European Court of Justice (ECJ) in its 2010 Brita case,$^{31}$ each of the two association agreements has its own territorial scope, and there is no overlapping between the two: the 1995 EC-Israel Association Agreement applies to the territory of the State of Israel (as per the 1949 armistice agreement), whereas the 1997 EC-PLO Interim Association Agreement applies to the territory of the West Bank and the Gaza Strip. For the ECJ, the customs authorities of each exporting country should have exclusive competence within their territorial jurisdiction to issue origin/ movement certificates. The ECJ emphasized that as a consequence, the 1995 EC-Israel Association Agreement cannot be interpreted in such a way as to compel the Palestinian authorities to waive their right to exercise the competence conferred upon them by virtue of the 1997 EC-PLO Interim Association Agreement. It follows that the 1995 EC-Israel Association Agreement "must be interpreted as meaning that products originating in the West Bank do not fall within the territorial scope of that agreement and do not therefore qualify for preferential treatment under that agreement." 32

More generally, state sovereignty, as John Ruggie maintains, is an attribute of "territorially defined, fixed and mutually exclusive enclaves of legitimate dominion," 33 indicating that a given territory cannot, according to international law, have two legal sovereigns simultaneously. This does not imply that the EU's decision regarding the implementation of the ROO lacked political motivation, but it does suggest that the claim about it being inconsistent or informed by a double standard is not accurate. In fact, the opposite is the case. The EU would be inconsistent and incoherent if it had failed to implement the ROO; the only way that the EU could ensure that its association agreements were not in conflict with each other was by insisting that the ROO clause in the EC-Israel Association Agreement would be implemented. Lack of implementation, therefore, became a matter of legal incongruity, so that even Israel's longstanding allies in Europe had to support it.

\section{THE ROO'S IMPACT ON ISRAELI INDUSTRY IN THE TERRITORIES}

Insofar as the EU's imposition of the technical customs rules was aimed at putting pressure on Israel to stop investing in its settlement project, then it is important to ascertain whether the implementation of the ROO has actually had an impact on Israeli industry in the Territories or on Israel's settlement policies. According to a report by Who Profits, an Israeli NGO monitoring industry in the Territories, there are 136 companies in the Territories that export goods to European countries. Of these, 125 have

31. Firma Brita GmbH v. Hauptzollamt Hamburg-Hafen, No. C 386/08, 2010 EUR-Lex LEXIS, 63 (ECJ, February 25, 2010).

32. Firma Brita GmbH, 2010 Eur-Lex LEXIS 63, Paragraph 53; In this context one should also be reminded of the 2004 Advisory Opinion of the International Court of Justice (ICJ) regarding the legal consequences of the construction of a wall in the Territories. The ICJ was of the opinion that Israel's construction of the wall in the Territories was contrary to international law. International Court of Justice, "Advisory Opinion on Legal Consequences of the Construction of a Wall in the Occupied Palestinian Territory," International Legal Materials, No. 43 (2004), p. 1009.

33. John Gerard Ruggie, Constructing the World Polity: Essays on International Institutionalization (Abingdon, UK: Routledge, 1998), p. 180. 
offices in the West Bank, seven in the Golan Heights, and four have plants in both the West Bank and the Golan Heights. The majority of these companies (94) have headquarters inside Israel's pre-1967 borders, while the headquarters of 35 companies are in the Territories, and the remaining are production plants of companies from Belgium, France, Italy, the Netherlands, Singapore, the United Kingdom, and the United States. The industry itself is made up of construction companies (36), low-tech manufacturers (34), food supplies and agriculture (29), banking and investment (12), security industry (8), marketing (8), transportation (5), and communications, services and high tech (4). ${ }^{34}$ The implementation of the ROO on these companies entails the enforcement of customs duties on products exported to the EU.

While we do not have up-to-date data about the volume of exports from the Territories, in 2003 these exports amounted to $\$ 120$ million, comprising about $0.6 \%$ of Israel's total exports during the same year. ${ }^{35}$ Since about $30 \%$ of Israel's exports go to the EU, ${ }^{36}$ we can assume that about $\$ 40$ million would have been subjected to customs duties. Accordingly, if the ROO were strictly imposed, it would have only a limited impact on Israel's overall trade. However, Israel wanted to make sure that the implementation of the ROO would not have any impact whatsoever on the industry in the Territories, since the relocation of companies from the Territories back to Israel would have internal political consequences on the settlement project. Consequently, immediately after the EU and Israel reached their December 2004 "technical arrangement" on the ROO dispute, Israel established a "national compensation mechanism" for Israeli exporters from the settlements whose exports were refused preferential status by the EU's customs authorities.

In its 2006 budget, Israel introduced a new budget line "directive number 320408 : exporters' compensation." The directive explains:

the State of Israel has trade agreements with a large number of countries in the world. For political reasons, [EU] member states decided in recent years to prevent duties reduction as established in these agreements for Israeli products produced beyond the Green Line. Due to the resultant loss of income, the Government of Israel compensates the farmers and industrialists operating beyond the Green Line. ${ }^{37}$

About $\$ 8$ million were allocated for reimbursement in $2006,{ }^{38}$ but by 2011 , the money transferred to the fund was reduced to $\$ 3$ million..$^{39}$ In the fiscal years 2013 and 2014, this budget line was merged with three other budget lines under the title "various kinds

34. All the data is from Who Profits, www.whoprofits.org.

35. State of Israel, Central Bureau of Statistics (hereafter CBS), "Statistical Abstract of Israel, No. 55," 2004.

36. In 2013, 34\% of Israel's imports (excluding diamonds) came from the EU and $32 \%$ of its exports (excluding diamonds) were directed to the European market; CBS, "Foreign Trade, 2013," www.cbs.gov.il/www/presentations/maz_nis_2013.pdf, pp. 24-25.

37. State of Israel, Ministry of Finance (hereafter MOF), "Taktsiv ha-Medinah: Hatsa 'ah li-Shenot ha-Kesafim 2011-2012" ["State Budget: Proposal to Fiscal Years 2011-2012”], October 2010, http:// mof.gov.il/BudgetSite/statebudget/Budget2011_2012/Documents/Budget2011_2012.pdf.

38. Sapir Peretz, "Shokhvim 'al ha-Gader" ["Lying on the Fence"], Globes [Israel], February 27, 2006.

39. MOF, "Pirte ha-Taktsiv li-Shenat 2011" ["Details of the Budget for the Year 2011"], Art. \#0408, October, 2010, p. 5. 
of annual support," ${ }^{40}$ and only about $\$ 1.9$ million were allocated for the "national compensation mechanism" for each fiscal year (we explain in the subsequent pages some of the reasons for the reduced allocations). ${ }^{41}$ Hence, we can conclude that the ROO has affected no more than $0.5 \%$ percent of Israeli exports. This exact figure was also confirmed by two different officials of the European External Action Service (EEAS), who are working on EU-Israeli relations. ${ }^{42}$ Moreover, if the implementation of the ROO aimed at imposing an economic fine for being located in the Territories, then the State of Israel absorbs the cost and in this way guarantees that these companies do not lose capital. In this way, the State helps ensure that they stay in the Territories.

It seems that the companies themselves have introduced strategies to deflect the economic and political impact of the ROO, primarily by obscuring the origin of the exported goods. As noted, the headquarters of most Israeli exporting companies in the Territories are not located in the West Bank or the Golan Heights, while some of the companies whose headquarters are in the Territories have outlets or plants inside Israel proper. At times, the manufacturing process of the exported good takes place in both Israel proper and the Territories. All of this enables the Israeli companies in the Territories to use an undisputedly Israeli address when exporting settlement goods to EU markets and bypass the ROO.

There are further strategies to get around the ROO. As the deputy director general of the Arza Winery, located in the Adumim Industrial Park in the West Bank, explained:

we are successful in overcoming the boycott by using other companies or distributors who are operating abroad. There is no direct export to the country of destination but rather through a third company. Sometimes we play with the label on the bottle. The English label states that we operate from Israel but it does not state that it is from Mishor Adumim, but rather from Adumim [Industrial] Park. ${ }^{43}$

The State's funds used to reimburse companies that are obliged to pay customs duties dropped by over half from 2006 to 2011, which suggests that these strategies have been widely used.

Furthermore, we are aware of only two out of 136 Israeli companies in the Territories that have actually moved back to Israel proper. ${ }^{44}$ It does not seem likely that the

40. MOF, "Taktsiv ha-Medinah: Hatsa'ah li-Shenot ha-Taktsiv, 2013-2014" ["State Budget: Proposal to Fiscal Years, 2013-2014”], Directive \#325004, June 2013, http://mof.gov.il/BudgetSite/ statebudget/BUDGET2013_2014/Documents/MainBudgetFull_2013_2014.pdf, pp. 154-56.

41. MOF, "Pirte ha-Taktsiv li-Shenat 2013" ["Details of the Budget for the Year 2013"], Art. \#500401, June 2013; MOF, "Pirte ha-Taktsiv li-Shenat 2014" ["Details of the Budget for the Year 2014"], Art. \#500401, June 2013. For a specific budget line per fiscal year see State of Israel, "Ma'arekhet She'iltot Mekuvenet le-Taktsiv ha-Medinah u-Vitsu'o" ["Online Query System for the State Budget and Its Execution"], http://religinfoserv.gov.il/magic94scripts/mgrqispi94.dll?APPNA $\mathrm{ME}=$ budget $\&$ PRGNAME=takzivreq.

42. Interviews by the authors with senior officials at the EEAS, April 18, 2013, Brussels/Berlin; July 15, 2013, Ramat Gan; and November 13, 2013, Brussels.

43. Noam (Dabul) Dvir and Attila Somfalvi, "'Herem? Gam ha-Falestinim ve-Gam ha-Yisra'elim Yipag ' $u$ "' [“'Boycott? Both Palestinians and Israelis Would Be Harmed'”], Yedioth Ahronoth, February 3, 2014, www.ynet.co.il/articles/0,7340,L-4483794,00.html.

44. Interview by authors with Yara Sa 'di of Who Profits, January 30, 2012, Beersheba; Jodi Rudoren, "Israeli Firm, Target of Boycott, to Shut West Bank Plant," The New York Times, October 30, 2014, www.nytimes.com/2014/10/31/world/middleeast/sodastream-to-close-factory-in-west-bank.html. 
major reason for relocating was due to the implementation of the ROO, since companies have not incurred any real financial loss, while the fact that the companies continue to label their products "Made in Israel" makes it extremely difficult to organize a consumer front against their products. Therefore, the implementation of the ROO has not engendered a serious negative incentive for these companies to move.

Finally, since the implementation of the ROO, Israel has only further entrenched its settlement project. ${ }^{45}$ In 2013, 2,534 apartment units were under construction in the West Bank, more than double the amount the previous year $(1,133) .{ }^{46}$ Between January and April 2014, the Israeli government announced that it would build a total of 6,672 new units in the Territories, despite ongoing criticism from the EU. ${ }^{47}$ A March 18, 2014 internal report written by EU diplomats stationed in Jerusalem and Ramallah underscored "the unprecedented surge in settlements activity" since negotiations resumed in July 2013. This, the authors of the report maintain, appears to be part of Israel's strategy to use settlement construction and infrastructures "to expand Jerusalem deeply into the West Bank." 48

\section{THE RULES OF ORIGIN AND LABELING LAWS}

The implementation of the ROO and their deployment as an instrument of European foreign policy towards Israel has not directly bore fruit. One of the reasons for the lack of impact involves the December 2004 "technical arrangement" the EU hammered out with Israel, whereby the goods originating from the Territories continue to be labeled "Made in Israel." The decision not to change the labels of Israeli goods produced in the Territories has to do with the fact that the ROO are not directly tied to labeling laws, and that with few exceptions labeling rules are decided by each EU member state. Currently, "the limited available tools" at the EU level consist of Directive 2000/13 on food labeling, which requires consumer labels on the "true origin" of goods, ${ }^{49}$ as well as Directive 2005/29 on unfair commercial practices. ${ }^{50}$ Based on these "limited tools,"

45. Neve Gordon and Yinon Cohen, "Western Interests, Israeli Unilateralism, and the Two-State Solution," Journal of Palestine Studies, Vol. 41, No. 3 (Spring 2012), pp. 6-18.

46. Foundation for Middle East Peace (FMEP), "West Bank Construction Update," Report on Israeli Settlement in the Occupied Territories, Vol. 24, No. 2 (Mar./Apr. 2014), p. 10, www.fmep.org/ reports/archive/vol-24/vol-24/PDF.

47. FMEP, "Settlement Expansion Announcements, 2014 (units)," Report on Israeli Settlement in the Occupied Territories (Mar./Apr. 2014), p. 5.

48. Amira Hass, "EU Diplomats Warn of Regional Conflagration over Temple Mount," Haaretz, March 28, 2014, www.haaretz.com/news/diplomacy-defense/.premium-1.582532.

49. "Directive 2000/13/EC of the European Parliament and of the Council of 20 March 2000," Official Journal of the European Communities, \#L 109 (May 6, 2000), p. 29, Article 3(8), http://eur-lex. europa.eu/LexUriServ/LexUriServ.do?uri=OJ:L:2000:109:0029:0042:EN:PDF.

50. "Directive 2005/29/EC of the European Parliament and of the Council of 11 May 2005," Official Journal of the European Union, \#L 149/22 (June 11, 2005), Article 6, http://eur-lex.europa.eu/LexUriServ/LexUriServ.do?uri=OJ:L:2005:149:0022:0039:en:PDF; Of importance are also Regulation 178/2002 on food, that contains pro-labeling provisions which can be called into action, see "Regulation (EC) No 178/2002 of the European Parliament and of the Council of 28 January 2002," Official Journal of the European Communities, \#L 31/1 (February 1, 2002), Article 16, http://eur-lex.europa.eu/LexUriServ/LexUriServ.do?uri=OJ:L:2002:031:0001:0024:EN:PDF; for the fruit and vegetable sectors, "Commission Regulation (EC) No 1580/2007 of 21 December 2007," 
in July 2014, the EU warned the Israeli agriculture ministry that it was not allowed to supply permits for the export of poultry which originates in the OT. The EU asked the ministry's veterinary services unit to differentiate between products made in "Israel proper and those produced in the territories," making it clear that "unless Israel comes up with a sufficiently effective mechanism," it might impose a ban on all Israeli meat, poultry, and dairy products. ${ }^{51}$

A "non-binding EU code of conduct" on labeling settlement-produced food might be ready only by mid-2015, and the EU code "covering all exports, including wine and cosmetics, could take much longer." 52 An EU official interviewed by EUobserver in September 2012 even admitted that "the mixture of EU laws is so messy [that] "it could take years' before a code of conduct on labelling of all settlement exports is ready" (emphasis added)..$^{53}$

Another legal obstacle involving the enforcement of labeling has to do with the fact that the EU signed two association agreements, one with Israel and the other with the PLO, and that both lay claim to the same territory. As was discussed earlier, according to the Brita case, it would be legally impossible to label Israeli goods produced in the Territories as "Made in Israel — Occupied Territories," since goods from the Territories must enter EU markets only under the 1997 EC-PLO Interim Association Agreement. ${ }^{54}$

Both these obstacles are significant, and yet the upshot is that the 2004 "technical arrangement" ends up misleading consumers and makes it impossible for them to know the real origin of Israeli goods that are produced in the Territories. One can hardly expect that European consumers would use the European Commission's list of noneligible locations and their postal codes in their daily shopping. Put differently, because the 2004 arrangement, with some minor exceptions, de-links the ROO from labeling, it has deflected potential consumer action against settlement products on the basis of the information made available to them. This is because the ROO operate in a top-top manner, in the sense that officials determine which products are not included in the PTA and impose upon them a customs duty. Thus, the pertinent information remains at the top and none of it is readily accessible to the end user. In this way, the ROO deflects the power of the local — in this case, EU citizenry — from weighing in through, for example, consumer boycotts. By contrast, and with some exceptions, labeling operates in a top-down manner. The labeling itself is determined by officials according to state laws, but the information about where the goods are produced is clearly marked and

[Continued from previous page]

Official Journal of the European Union, \#L 350/1 (December 31, 2007), http://eur-lex.europa.eu/LexUriServ/LexUriServ.do?uri=OJ:L:2007:350:0001:0098:EN:PDF; and in the wine sector, "Council Regulation (EC) No 479/2008 of 29 April 2008," Official Journal of the European Union, \#L 148/1 (June 6, 2008), http://eur-lex.europa.eu/legal-content/EN/TXT/PDF/?uri=CELEX:32008R0479\&from=en.

51. "EU Threatens Israel with a Total Ban of Poultry Unless It Marks Products from Settlements," The Jerusalem Post, September 2, 2014, www.jpost.com/Israel-News/Politics-And-Diplomacy/EUthreatens-Israel-with-total-ban-of-poultry-unless-it-marks-products-from-settlements-374177.

52. Andrew Rettman, "Leading EU Countries to Stigmatise Israeli Settler Goods," EUobserver, April 22, 2013, http://euobserver.com/foreign/119883.

53. Andrew Rettman, "EU Working on Consumer Labels for Israeli Settlement Products," EUobserver, September 14, 2012, http://euobserver.com/foreign/117547.

54. Firma Brita GmbH, 2010 Eur-Lex LEXIS 63. 
ends up reaching EU citizens, which gives them an opportunity to act. The assumption here is that the EU citizenry have power, but they need knowledge in order to use it; the ROO does not provide them this knowledge, while labeling does. Hence, the de-linking between the ROO and labeling of most Israeli exports to European markets has effectively disempowered EU citizenry and, in this way, has stripped the technical customs rules of their potential ability to have an impact on an active European foreign policy.

\section{THE ASSERTION OF “AN ECONOMIC GREEN LINE” AND THE EU'S SELF-IDENTIFICATION AS A NORMATIVE POWER}

Notwithstanding the lack of direct impact, the ROO's implementation has had a number of interesting, if not always intended, effects on Israeli industry in the Territories and Israel's settlement project. Wittingly or unwittingly, when implementing the ROO, the EU did not seem to have taken into account Israel's economic borders. Israel does not have two separate economies, one in the pre-1967 borders and another in the Territories. A 2010 research paper about Israeli banks, for example, shows that the banks in pre-1967 Israel:

provide[d] the financial infrastructure for all activities of companies, governmental agencies and individuals in the continuing occupation of Palestine and the Syrian Golan Heights. The services provided by the banks support and sustain these activities. ${ }^{55}$

Moreover, the customs and monetary regimes are the same in pre-1967 Israel and in the Territories. It is therefore no surprise that most of the companies operating in the Territories have headquarters or plants in Israel proper, allowing them to avert the European customs duties by providing a postal code in Israel.

By promulgating the notion that Israel's economy is severed from the occupation, the ROO provide the EU with normative legitimation to deepen its trade ties with Israel despite its displeasure with Israel's settlement project, since the EU can accurately proclaim that it is simultaneously sanctioning Israeli industry in the Territories. The problem with this strategy is that the use of customs rules to reassert a nonexistent economic border can to reinforce the existing status quo. Put differently, the implementation of the ROO has provided Israel's economy normative legitimation by inserting an imaginary distinction between Israel's pre-1967 economy and its economy in the Territories.

Consequently, by imposing the ROO, the EU's self-identification as a "normative power" is bolstered. ${ }^{56}$ This latter point requires further explanation. From its first attempt to craft a unified foreign policy in the early 1970s as the European Political Cooperation (EPC), the EU understood that European identity would evolve as a function of the dynamic construction produced progressively through the member states'

55. The Coalition of Women for Peace and Who Profits, "Financing the Israeli Occupation: The Direct Involvement of Israeli Banks in Illegal Israeli Settlement Activity and Control Over the Palestinian Banking Market," Who Profits from the Occupation Report, October 2010, http://whoprofits. org/sites/default/files/WhoProfits-IsraeliBanks2010.pdf.

56. Manners, "Normative Power Europe." 
relation to other countries or groups of countries. ${ }^{57}$ By defining common positions towards countries and other regions such as the Mediterranean and the Middle East, the EU constitutes its own identity as a distinct and unitary actor. ${ }^{58}$ Our claim is that as a form of normative power, the ROO serve to build the EU's own identity and to solidify the unity among the member states.

The incentive to implement the ROO was, in other words, not only to impact Israeli policies in the Territories, but also to influence the identity of member states and their citizens by producing a common normative claim. The EU's long-standing normative position that Israel's occupation is illegal helps constitute its own identity when the discursive citation of this position is internalized within local European institutions, agencies, and legislation. ${ }^{59}$ For the normative position to be effective as a solidifying device, for it to be an inward bound mechanism that helps produce a unified identity, the norms - in this case the claim that Israel's occupation is illegal — have to manifest themselves in actual policies and practices; they have to be seen, and not merely heard. In this way, the implementation of the ROO played a role in institutionalizing a norm that also has an inward bound role. ${ }^{60}$

\section{THE RULES OF ORIGIN'S INCREMENTAL IMPACT}

Although the ROO assert an imaginary economic border and have not had a direct impact on Israeli policies in the Territories, their implementation has produced an important legal precedent that has served to legitimize a series of other actions that, over the past decade, have taken place at three distinct levels: the supranational, national, and private, corporate/financial entities. While these actions have been propelled by numerous factors, all of them have in common the notion that conducting business with Israeli companies either located in the Territories or complicit in the occupation can be legally problematic. At the time of publication, it appears that the European campaign to boycott Israeli companies and institutions is gaining strength and we are witnessing the beginning of a snowball effect whereby these disparate actions are actually coalescing and together are beginning to influence Israeli decision-makers.

Chronologically, the implementation of the ROO impacted member states first. A few member states understood that the de-linking of the ROO from labeling in practice defanged the ROO clause, but decided to use the clause in order to legitimize the

57. See for example Article 22 of the 1973 Copenhagen European Summit, excerpted in Centre Virtuel de la Connaissance sur l'Europe (CVCE), "Declaration of European Identity (Copenhagen, 14 December 1973)," CVCE website, December 18, 2013, www.cvce.eu/content/ publication/1999/1/1/02798dc9-9c69-4b7d-b2c9-f03a8db7da32/publishable_en.pdf, p. 4.

58. Article 13 in CVCE, "Declaration on European Identity," pp. 3-4.

59. Thomas Diez, "Constructing the Self and Changing Others: Reconsidering "Normative Power Europe," Millennium: Journal of International Studies, Vol. 33, No. 3 (Jun. 2005), pp. 613-36.

60. Having said this, more research needs to be carried out on the impact the Union's longstanding normative position regarding Israel's occupation has had on EU identity, since as Thomas Diez has recently pointed out, treating normative power as constituting the identity of the EU "overrates the stability of the discourse and underrates the contested-ness of normative power as a core concept"; Thomas Diez, "Setting the Limits: Discourse and EU Foreign Policy," Cooperation and Conflict, Vol. 49, No. 3 (Oct. 2014), p. 330. See also Neve Gordon and Sharon Pardo "Normative Power Europe Meets the Israeli Palestinian Conflict," Asia Europe Journal (forthcoming, 2015). 
adoption of new national labeling laws. In 2008, the UK called on the EU to be stricter in its application of the 1995 EC-Israel Association Agreement, reminding Israeli and European officials that goods produced beyond the 1967 borders should be labeled as originating in Jewish settlements in the Territories. The UK holds that these products should be distinguished from Palestinian industrial, agricultural, and other goods. ${ }^{61}$

Along similar lines, in May 2012, the Danish Politiken newspaper reported that Denmark, then the rotating president of the Council of the EU, was planning to ban the labeling of products from Israeli settlements in the Territories as "Made in Israel." According to the Danish foreign minister at the time, Villy Søvndal,

this is a step that clearly shows consumers that the products are produced under conditions that not only the Danish government, but also European governments do not approve. ... It will then be up to consumers whether they choose to buy the products or not. ${ }^{62}$

The Danish moves followed reports of similar plans announced in May 2012 by South Africa's government. ${ }^{63}$ On April 11, 2013, foreign ministers of 13 EU member states signed a joint letter to the Union's high representative, Catherine Ashton, in which they noted that "the correct labelling of products is necessary to ensure our consumers are not being misled by false information." ${ }^{4}$ All these countries understand that by delinking the ROO from labeling they have possibly misled their citizenry and have thus prevented them from using their power to influence both national and European foreign policies. In many of these countries there are current initiatives to introduce labeling laws that forbid settlement products to be labeled "Made in Israel."

On the supranational, EU level, it appears that the ROO created the necessary legal groundwork for new guidelines prohibiting the allocation of EU funds to Israeli companies, public bodies, and NGOs working within the Israeli settlements. ${ }^{65}$ The guidelines cover the new EU research program Horizon 2020, which entered into effect in January 2014, replacing the Seventh EU Framework Programs for Research and Technological Development (FP7). Following the 1995 EC-Israel Association Agreement and in line with the 2010 Brita ruling of the ECJ, the guidelines make it clear that the EU does not recognize Israel's sovereignty over the Territories, irrespective of their legal status under Israeli law. ${ }^{66}$ Hence, the guidelines are based on the same logic informing the ROO and use the Brita ruling as precedent, but expand it to include the dispensation of funds, grants, and awards to Israeli companies, NGOs, and institutions in the Territories.

61. Department for Environmental, Food and Rural Affairs (UK) (hereafter DEFRA), "Technical Advice: Labeling of Produce Grown in the Occupied Palestinian Territories," December 10, 2009, available on the DEFRA website, http://archive.defra.gov.uk/foodfarm/food/pdf/labelling-palestine.pdf.

62. Amira Haas, Barak Ravid, and Anshel Pfeffer, "Denmark to Ban Labeling West Bank Products as 'Made in Israel,' Report Says," Haaretz, May 19, 2012, www.haaretz.com/news/diplomacydefense/denmark-to-ban-labeling-west-bank-products-as-made-in-israel-report-says-1.431372.

63. Department of Trade and Industry (South Africa), "General Notice: Notice 379 of 2012" National Gazette, No. 35328 (May 10, 2012).

64. Rettman, "Leading EU Countries to Stigmatise Israeli Settler Goods."

65. EC "Guidelines on the Eligibility of Israeli Entities."

66. EC "Guidelines on the Eligibility of Israeli Entities," Articles 2, 3. 
Finally, companies and financial institutions in different EU countries have begun divesting from Israeli institutions that are complicit with the occupation. These include PGGM, the largest Dutch pension fund, that decided to divest from Israeli banks, ${ }^{67}$ and Denmark's largest bank, Danske Bank, that decided to pull its investment from Israel's Bank Hapoalim due to the latter's involvement in settlement construction. Danske Bank's decision followed its previous divestment from Africa Israel Investments Ltd., another firm that is involved in settlement construction. ${ }^{68}$ While there is no causal relation between the implementation of the ROO and the decisions of these financial institutions, the ROO and the Brita ruling draw a legal distinction between pre-1967 Israel and the Territories - suggesting also that Israel's presence in the latter is illegal - that is pertinent to all European institutions. In this way, it serves both as the legal foundation and as a mechanism of legitimization for the decisions reached by these financial institutions.

\section{CONCLUSION:}

\section{THE RULES OF ORIGIN AS INSTRUMENTS OF FOREIGN POLICY}

While we agree with Hirsch that the rules of origin (ROO) "may promote the foreign policy interests of a country or economic block [sic]," 69 we believe that the ways and extent they impact politics are extremely complex. We began by showing that the implementation of the ROO had no direct impact on Israeli industry in the Occupied Territories or on Israel's settlement project. Simultaneously, the imposition of the ROO clause created an imaginary economic border between pre-1967 Israel and the Territories and, in this way, helped legitimate business as usual between the European Union and Israeli firms. The implementation of the ROO justified the preferred trade agreement (PTA) between the two parties. Thus, initially it appears that if the ROO had an impact, it was unintended and even contradicted the original objective of implementation. Imposing the ROO did, however, serve to bolster the EU's self-identification as a "normative power." In this sense, the implementation of ROO has played a role in institutionalizing a norm that has an inward bound role.

Finally, we claimed that the implementation of the ROO and the Brita ruling have also had an incremental effect in that they created a legal precedent that helps justify the initiation of a series of other actions that use commerce to underscore the illegality of Israel's occupation. Providing a number of examples, we showed that these actions take place on three levels: supranational, national, and private, corporate/financial institutions. While more research needs to be carried out, it appears that together these actions produce a normative web that makes demands on Israel, on other EU institutions, and on private entities so that they too will adopt a similar normative position.

67. PGGM, "Statement Regarding Exclusion of Israeli Banks."

68. Barak Ravid, "Denmark's Largest Bank Blacklists Israel's Hapoalim Over Settlement Construction," Haaretz, February 1, 2014, www.haaretz.com/news/diplomacy-defense/1.571849.

69. Hirsch, “The Politics of Rules of Origin," p. 320. 